\title{
PERFORMANCE AND COMBINING ABILITY FOR STRAW YIELD AND RELATED CHARACTERS IN A DIALLEL CROSS OF FLAX (Linum usitatissmum, L.) UNDER DIFFERENT SOWING DATES
}

\author{
Amany N. Sayed ${ }^{1 *}$, El-Marakby ${ }^{1}$ A.M., Afaf M. Tolba ${ }^{1}$ \\ and Sabah M. Abo El-Komsan ${ }^{2}$
}

1- Agronomy Dept., Fac. of Agric., Ain Shams Univ., P.O. Box 68-Hadayek Shoubra 11241, Cairo, Egypt

2- Fiber Crops Res. Dept., Field Crops Res. Inst., Agric. Res. Center, P.O. Box 12619, Giza, Egypt

*Corresponding author: amany87323@agr.asu.eg

Received 11 April, $2019 \quad$ Accepted 30 April, 2019

\begin{abstract}
Thirty six entries of flax (Linum usitatissmum, L.) involving eight parental genotypes and their twenty eight hybrids were evaluated for straw yield and its related traits in the $F_{1}$ during $(2015 / 2016)$ and $F_{2}$ populations during $(2016 / 2017)$ under early $\left(F_{2} D 1\right)$ and late $\left(F_{2} D 2\right)$ sowing dates (two environments) in the Agricultural Research Station, Faculty of Agriculture, Ain Shams Univ., Shalakan, Kalubia Governorate. Mean squares due to genotypes, parents and crosses were highly significant for straw yield, plant height, technical stem length, fiber yield/plant, fiber percentage, fiber length and fiber fineness in the $F_{1}$ and $F_{2}$ generations (at early and late sowing dates), indicating that parental genotypes as well as their $F_{1}$ and $F_{2}$ generations exhibited reasonable degree of variability for all studied traits. Highly significant variations mean performance were found for parental genotypes and hybrids for straw yield/plant and its related

straw yield and its components. The additive effects were more important than non-additive effects under all studied environments for straw yield/plant (except at $\mathrm{F}_{2} \mathrm{D} 2$ ), plant height (except at $F_{1}$ ), fiber percentage and fineness. On the other hand, the non- additive effects were more effective than additive effects for technical stem length, fiber yield/plant and fiber length. Results showed that the parents; Giza 11and Giza 12 for straw yield/plant, Sakha 5 for plant height and fiber length, Sakha 6 for fiber yield/plant, Jowhar for fiber percentage and S. 402/1, Sakha 2, Giza 12 and Sakha 5 for fiber fineness, these parents appeared to be the best general combiners for these traits. Some of the crosses exhibited highly significant and positive SCA effects included high $\mathrm{x}$ high and high $x$ low general combiner parents, suggesting that the breeding procedure which utilize both additive and non-additive genetic variances would be more useful for improvement of straw yield and its components of flax.
\end{abstract} traits in the $F_{1}, F_{2} D 1$ and $F_{2} D 2$, indicating presence of wide genetic variability among studied genotypes. The highest mean values were recorded under all studied environments, for straw yield/plant, fiber yield/plant and fiber fineness were found by S. 402/1 genotype, while Sakha 5 gave the highest mean values for plant height, technical stem length and fiber length.

General and specific combining ability mean squares were highly significant for all studied traits in $F_{1}, F_{2} D 1$ and $F_{2} D 2$ with the exception of a few cases, indicating the importance of both additive and non-additive gene effects in the expression of
Keywards: Flax, Performance, Combining ability, Additive, Non-additive, Sowing dates.

\section{INTRODUCTION}

Linseed or Flax (Linum usitatissimum, L.) is a traditional oilseed just as a fiber yield and has a place with Linaceae family with chromosome number 30. Flax has dependably had mechanical utilizations; as of late its uses have extended to incorporate a scope of new potential outcomes, for example, cigarette papers, vehicle entryway boards 
and packed sheets. In any case, to an everincreasing extent, flax is cutting a specialty as a wellbeing nourishment. Alpha-linolenic corrosive (an omega-3 unsaturated fat found in seed flax) is fundamental in the human eating routine. It can diminish coronary illness and lower cholesterol. Flax is developed in Egypt for two purposes, seeds and filaments.

The diallel cross strategy proposed by (Griffing, 1956) has been broadly utilized for assessment of general joining capacity which is because of added substance quality activity and explicit consolidating capacity which is expected to nonadded substance quality impacts. The trouble in delivering enough $F_{1}$ mixture seeds in some selfpollinated crops have constrained the utilization of diallel examination, and in such cases, $F_{2}$ diallels might be increasingly fitting (Shehata and Comstock, 1971 and Patil and Chopde,1981).In any case, $F_{2}$ diallels gauge predominance with just a large portion of the effectiveness of $F_{1}$ diallels (Allard 1960). The added substance hereditary change had increasingly vital job in the legacy of straw yield, plant stature and specialized stem length as detailed by Foster et al 1998, El-Kady, Eman and Abo-Kaied 2002, Abo-Kaied et al 2007 and Abo-Kaied and El Refaie, Amany 2008. The targets of the present investigation are to estimate the magnitude of both general and specific combining ability for straw yield and its related characters in an eight parental diallel crosses of flax in $F_{1}$ and $F_{2}$ generations under two distinct conditions with an extreme objective of choosing appropriate guardians and the superiority crosses which can be utilized in reproducing program.

\section{MATERIALS AND METHODS}

Eight flax genotypes were chosen on basis of their diversity in some agronomic traits to achieve this study, i.e. two new strains (S.2465/1/3 and S402/1), five local cultivars (Sakha 6, Sakha 5, Giza 11, Sakha 2 and Giza 12) and the introduced cultivar (Gowhar). Seeds of the genotypes were obtained from Fiber Crops Research Section, Field Crops Research Institute, Agriculture Research Center (ARC), Giza. Genotype characteristics of the material used according to their names, type, pedigree and origin of the parental genotypes are presented in Table (1). This investigation was carried out during the three successive seasons $2014 / 15,2015 / 16$ and $2016 / 17$. In the first growing season (2014/15), the eight parents were crossed to form a half diallel set to obtain the seeds of parents and their $28 F_{1}$ crosses. Hybridization was made in the Experimental Farm at the Faculty of Agriculture, Ain Shams Univ. at Shoubra ElKheima, Kalubia Governorate, Egypt. In the second growing season (2015/16), seeds of parents and their twenty eight $F_{1}$ hybrids (36 entries) were sown on $14^{\text {th }}$ November 2015/2016 in the Agricultural Research Station, Faculty of Agriculture, Ain Shams University at Shalakan, Kalubia Governorate to obtain the seeds of parents and their twenty eight $F_{2}$ hybrids. In the third growing season (2016/17), seeds of each parent as well as seeds of each segregating $F_{2}$ cross were cultured in three rows. Parents and $F_{2}$ populations were sown in two sowing dates (two environments) one early date and the other late. The early date was on $6^{\text {th }}$ November (D1) while the late date was on $28^{\text {th }}$ November (D2). The preceding summer crop in the second and third growing seasons was soybean (Glycin max, L.). Other cultural practices were followed as recommended for flax production. The field experiments were designed in a randomized complete blocks (RCBD) with three replications in the second and third growing seasons. Each experimental plot consisted of one row for each genotype in 2015/16 growing season and three rows in 2016/17 growing season. Each row was $2.5 \mathrm{~m}$ in length and $30 \mathrm{~cm}$ width, seeds were spaced at 10 $\mathrm{cm}$ within rows and one plant was left per hill.

At harvest, sample of 10 plants from each plot were collected from parents or $F_{1}$ 's whereas samples of 70 plants were collected from each plot of $\mathrm{F}_{2}$ segregating crosses. Data of the following characters were recorded for the two generations as follow:

1. Straw yield per plant: total weight in grams of the air-dried straw per plant after removing the capsules.

2. Plant height $(\mathrm{cm})$ : measured as the distance from the cotyledonary nodes up to uppermost capsule.

3. Technical stem length $(\mathrm{cm})$ : the length of the main stem between the cotyledons and the apical branching point.

4. Fiber yield/plant (g).

5. Fiber percentage: [fiber weight per plant (g)/ straw weight per plant $(\mathrm{g})] \times 100$.

6. Fiber length $(\mathrm{cm})$ : the majority fiber length/plant.

7. Fiber fineness $(\mathrm{Nm})$ : estimated in metrical number $(\mathrm{mg} / \mathrm{mm})$ according to (Radwan and Momtaz, 1966). 
Performance and combining ability for straw yield and related characters in a diallel cross of flax (linum usitatissmum, I.) under different sowing dates

Table 1. Name, type, pedigree and origin of the eight parental flax genotypes

\begin{tabular}{|c|c|c|c|c|}
\hline Name & & Type & Pedigree & Origin \\
\hline S. 2465/1/3 & P1 & Dual & Selected from Neelum (Indian) & Local strain \\
Sakha 6 & P2 & Dual & Giza $8 \times$ S. 2419/1 & Local c.v. \\
S. 402/1 & P3 & Dual & Giza $5 \times$ I. 235 U.S.A & Local strain \\
Sakha 5 & P4 & Oil & I. $2561 \times$ I. 370 & Local c.v. \\
Giza 11 & P5 & Dual & Giza $8 \times$ S. 2419/1 & Local c.v. \\
Sakha 2 & P6 & Dual & I. $2348 \times$ Hera & Local c.v. \\
Giza 12 & P7 & Dual & S. 2419/1 $\times$ S. 148/6/1 & Local c.v. \\
Jowhar & P8 & Oil & Introduction from India & India \\
\hline
\end{tabular}

Statistical procedures used in this study were done according to analysis of variance for randomized complete blocks design as outlined by (Snedecor and Cochran, 1980).

The analyses of variance for general and specific combining abilities were estimated according to (Griffing's, 1956) method 2 model 1.

\section{RESULTS AND DISCUSSION}

\section{Mean square estimates}

Analysis of variance presented in Table (2) indicated that mean squares due to all 36 genotypes as well as mean squares due to parents and crosses were highly significant for straw yield/plant, plant height, technical stem length, fiber yield/plant, fiber percentage, fiber length and fiber fineness in the $F_{1}$ and $F_{2}$ generations, revealing the presence of sufficient genetic variability existed in the studied genotypes. Consequently, various comparisons suggested to be done are valid and should be conducted to achieve the objectives of the present study. Hassanein et al (2012) stated that the mean squares exhibited highly significant effect for plant height, technical stem length and straw yield/plant.

\section{Mean performance of genotypes}

\section{Straw yield/plant}

Mean performance for parental genotypes and hybrids for straw yield/plant was presented in Table (3). Highly significant variations were found between genotypes for this trait in both seasons, indicating presence of wide genetic variability among studied genotypes. With regard to parents, S. $402 / 1$ recorded the heaviest straw yield/plant in
$F_{1}$ and $F_{2}$ (at early and late sowing dates) which gave values of $29.13,28.50$ and $23.63 \mathrm{~g}$, respectively. Jowhar variety recorded the lowest mean values for straw yield/plant giving 24.00, 21.67and $21.33 \mathrm{~g}$ in the same order.

With respect to the crosses, the average mean performance for straw yield for all crosses recorded 28.38, 27.21 and 23.73g in both seasons ( $F_{1}$, $F_{2} \mathrm{D} 1$ and $F_{2} D 2$ ), respectively. The highest mean performance values for this trait were obtained by flax crosses; P2xP5 (36.30, 34, 83 and $31.00 \mathrm{~g})$, P2xP7 (35.10, 35.67 and $30.67 \mathrm{~g}$ ) and P5xP7 $(36.60,33.50$ and $27.17 \mathrm{~g})$ in $F_{1}, F_{2} D 1$ and $F_{2} D 2$, respectively. On the other hand, the lowest mean performance values for this trait were obtained by the crosses P2xP4 (21.13g), P2xP6 (21.33g) and $\mathrm{P} 4 x \mathrm{P} 8(20.33 \mathrm{~g})$ in $\mathrm{F}_{1}, \mathrm{~F}_{2} \mathrm{D} 1$ and $\mathrm{F}_{2} \mathrm{D} 2$, respectively. It is clear from the results that the delay in the planting date $\left(\mathrm{F}_{2} \mathrm{D} 2\right)$ gave low values than the earlier in planting date $\left(\mathrm{F}_{2} \mathrm{D} 1\right)$ for straw yield/plant, indicating that the delay in planting date has a detrimental effect on this trait.

\section{Plant height}

Highly significant differences were observed between parents as well as crosses for plant height in the $F_{1}$ and $F_{2}$ generations (Table 3), indicating presence of wide genetic variability among genotypes. Regarding to mean performance of parents, data indicated that Sakha5 and S. $402 / 1$ were the tallest among all genotypes recording the highest mean values of $(114.50,113.80$ and $107.43 \mathrm{~cm})$ and $(110.70,113.30$ and 107.06 $\mathrm{cm})$ in the first season $\left(F_{1}\right)$ and early and late sowing dates in the second season $\left(F_{2}\right)$, respectively, while Giza 11 was the shortest parent which having mean values of $90.57,90.29$ and $84.67 \mathrm{~cm}$ in the same above order, respectively. The average 


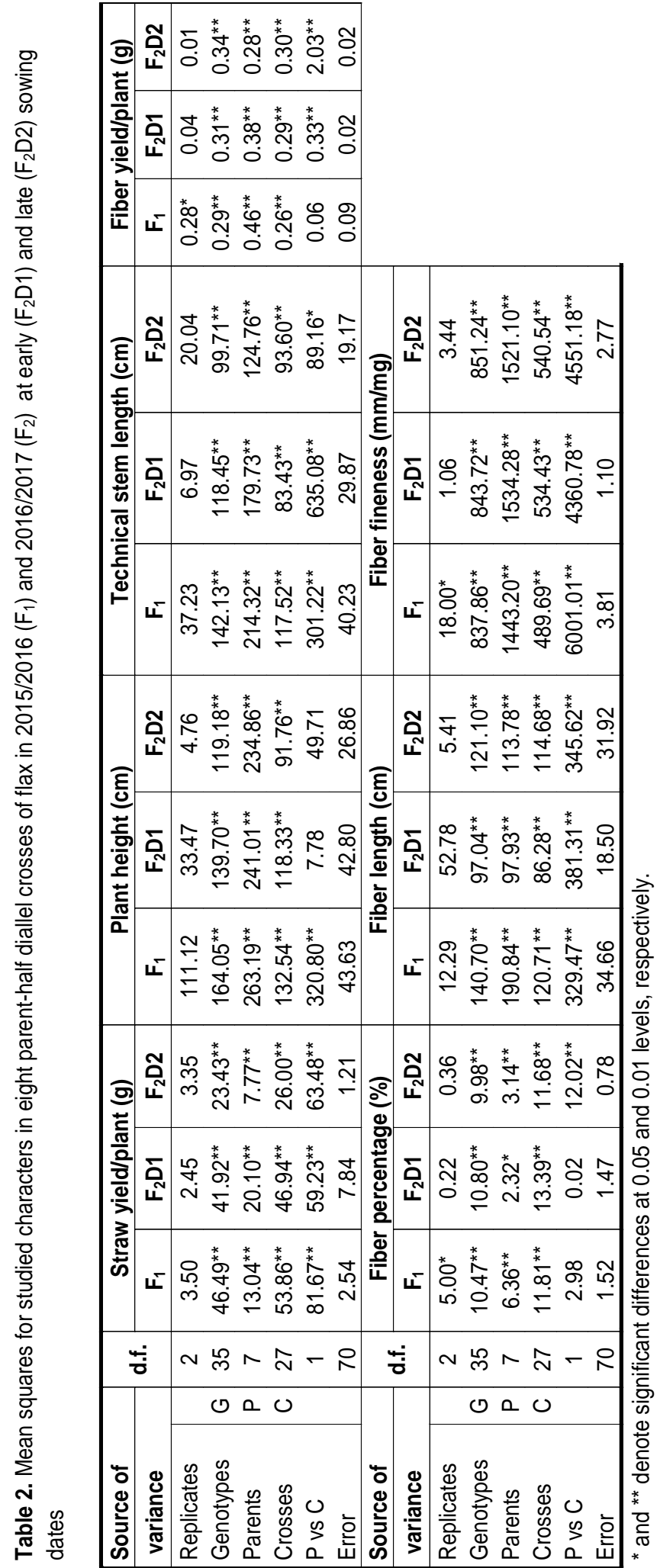


mean performance of parents recorded 100.76, 102.33 and $96.63 \mathrm{~cm}$ at the first season $\left(F_{1}\right)$ and early and late sowing dates in the second season $\left(F_{2}\right)$, respectively. These results showed that the delay in the planting date $\left(F_{2} D 2\right)$ gave low values than the earlier in planting date $\left(\mathrm{F}_{2} \mathrm{D} 1\right)$ for plant height, indicating that the plant height has been affected by environmental influences.

With respect to crosses, results illustrated that $\mathrm{P} 1 \mathrm{xP} 3$ and P4xP8 were the tallest crosses in the first season $\left(F_{1}\right)$ and early and late sowing dates in the second season $\left(F_{2}\right)$ which recording 113.30, 110.70 and $106.39 \mathrm{~cm}$ and $111.14,111.00$ and $105.72 \mathrm{~cm}$, respectively,. On the other hand, P1xP8 cross was the shortest parent with mean values of $87.70,88.80$ and $85.63 \mathrm{~cm}$ in the same order, respectively, with an average values of 104.91 , 102.97 and $98.26 \mathrm{~cm}$ in the first and early and late sowing dates in the second seasons, respectively. These results showed that the delay in the planting date $\left(F_{2} D 2\right)$ gave low values than the earlier in planting date $\left(F_{2} D 1\right)$ for plant height, indicating that the plant height has been affected by environmental influences.

\section{Technical stem length}

The mean performance of the studied genotypes for technical stem length was shown in Table (3) indicated that highly significant differences were observed between parents as well as crosses for technical stem length in the $F_{1}$ and $F_{2}$ (under two sowing dates) generations.

Mean performance values of the tested parental genotypes indicated that Sakha 5 and S. 402/1were surpassed the other parents in this trait and gave values of $78.83,76.87$ and 74.04 and $75.47,72.53$ and $69.66 \mathrm{~cm}$ in the first season $\left(F_{1}\right)$ and at early and late sowing dates in the second season $\left(F_{2}\right)$, respectively. On the other hand, Sakha 6 gave the lowest technical stem length giving respectively values of 54.41 and $54.27 \mathrm{~cm}$ in the $F_{1}$ and at early sowing date in $F_{2}$ generations, while Giza 11gave the lowest value $(53.72 \mathrm{~cm})$ at late sowing date in the $F_{2}$ generation. The average mean performance of crosses for technical stem length recorded $71.01,69.55$ and $65.52 \mathrm{~cm}$ in the $F_{1}$ and $F_{2}$ generations, respectively. The values of the 28 hybrids ranged from 54.72, 59.53 and $51.68 \mathrm{~cm}$ for (P2xP3) in $F_{1}$ and $F_{2} D 1$ and $F_{2} D 2$ generation, respectively, to $80.23 \mathrm{~cm}$ for ( $\mathrm{P} 1 \times \mathrm{P} 7)$, $78.37 \mathrm{~cm}$ for (P2xP5) and $72.34 \mathrm{~cm}$ for (P3xP6) in the $F_{1}$ and $F_{2} D 1$ and $F_{2} D 2$ generations, respectively. The general mean performance of technical stem length gave values of $70.12,68.25$ and $65.04 \mathrm{~cm}$ for the same above order, respectively. It is clear from the results that the delay in the planting date $\left(F_{2} D 2\right)$ gave low values than the earlier in planting date $\left(F_{2} D 1\right)$ for technical stem length, indicating that the delay in planting date has a reduction effect on technical stem length.

\section{Fiber yield/plant}

Men performance for 36 genotypes detected for fiber yield/plant is presented in Table (3). Significant or highly significant values were observed between these genotypes for this trait in both seasons, indicating presence of wide genetic variability among these genotypes. With regard to parents, the results illustrated that S. 402/1, Giza 11 and S. 2465/1/3) ranked in the first fiber yield/plant which gave values of $3.34,3.26$ and $2.58 \mathrm{~g}$ in the $F_{1}$ generation and at early and late sowing dates in the $F_{2}$ generation, respectively. On the other side, Sakha 2 produced the minimum values of fiber yield/ plant giving 2.28, 2.26 and $1.64 \mathrm{~g}$ in the same order, respectively. Respect to mean performance of crosses, the values of fiber yield/plant ranged from 2.33, and $1.94 \mathrm{~g}$ for (P1xP5) to 3.46 for (P5xP7), 3.73 and $3.35 \mathrm{~g}$ for (P4xP6) in the $F_{1}$ hybrid and early and late sowing dates in the $F_{2}$ hybrid, respectively. The average mean performance of crosses recorded 2.97, 2.99 and $2.52 \mathrm{~g}$ in the first season $\left(F_{1}\right)$ and early and late sowing dates in the second season $\left(F_{2}\right)$, respectively. It is clear from the results that the delay in the planting date $\left(F_{2} D 2\right)$ gave low values than the earlier in planting date $\left(F_{2} D 1\right)$ for fiber yield/plant, indicating that the environmental impacts have caused a reduction of fiber yield/plant.

\section{Fiber percentage}

Data of fiber percentage assessed for 36 flax genotypes at $F_{1}$ and $F_{2}$ generations during $2015 / 2016$ and $2016 / 2017$ growing seasons are presented in Table (3). The highest parents in fiber percentage were Giza 11, Sakha 6 and S. $2465 / 1 / 3$ which gave values of $12.50,12.44$ and $10.98 \%$ for fiber percentage in the first season $\left(F_{1}\right)$ and early and late sowing dates in the second season $\left(F_{2}\right)$, respectively. While Sakha 2 parent gave the lowest mean performance values of 8.90 , 10.13 and $7.91 \%$ for the same order, respectively.

The best crosses for this trait were P2xP4, P2xP6 and P4xP6 with mean values of 15.41, 15.18 and $16.42 \%$ in $F_{1}$ and early and late sowing 
dates in the second season $\left(F_{2}\right)$, respectively, in addition to, the cross (P2xP8) recorded 14.76, 14.33 and $13.60 \%$ for fiber percentage in the same order, respectively. On the other hand, the lowest mean values were recorded by $\mathrm{P} 3 \times \mathrm{P} 7$ (7.77\%), P2xP7 (7.89\%) and P3xP7 (7.71\%) in the $F_{1}$ and $\mathrm{F}_{2}$ generations, respectively. The average mean performance of crosses recorded 10.73, 11.30 and $10.80 \%$ for the $F_{1}$ and early and late sowing dates in the $F_{2}$ generations. It is clear from the results that the delay in the planting date $\left(\mathrm{F}_{2} \mathrm{D} 2\right)$ gave low values than the earlier in planting date $\left(\mathrm{F}_{2} \mathrm{D} 1\right)$ for fiber percentage, indicating that the delay in planting date has a reduction effect on fiber \%.

\section{Fiber length}

Significant or highly significant differences were observed between parents as well as crosses for fiber length in the $F_{1}$ and $F_{2}$ generations (Table 3), indicating presence of wide genetic variability among genotypes. Mean performance of parents, data indicated that Sakha 5 was the tallest among all genotypes recording the highest mean values of $(76.30,68.50$ and $67.18 \mathrm{~cm})$ in the first and second seasons, respectively, while Giza 11 was the shortest fiber length parent with mean values of 53.70 and $48.78 \mathrm{~cm}$ in the $F_{1}$ and late sowing date in the $F_{2}$ generations, respectively, but Sakha 6 was the shortest for the same trait which recorded $51.50 \mathrm{~cm}$ at early sowing date in the $F_{2}$ generation.

With respect to crosses, results illustrated that the values of fiber length ranged from 52.10 and $44.69 \mathrm{~cm}$ for (P2xP3) to 77.53 and $69.48 \mathrm{~cm}$ for $(\mathrm{P} 1 \times \mathrm{P} 7)$ in the first season $\left(\mathrm{F}_{1}\right)$ and late sowing date in the second season $\left(F_{2}\right)$, respectively, and from 51.32 for (P1xP8) to 71.68 for (P5xP7) at early sowing date in the $F_{2}$ generation. The average mean performance of crosses recorded 68.40, 62.66 and $60.37 \mathrm{~cm}$, in the $F_{1}$ and early and late sowing dates in the $F_{2}$ generations, respectively, These results showed that the delay in the planting date $\left(F_{2} D 2\right)$ gave low values than the earlier in planting date $\left(\mathrm{F}_{2} \mathrm{D} 1\right)$ for this trait, indicating that the fiber length has been affected by environmental influences.

\section{Fiber Fineness}

As shown in Table (3) the results indicated that significant or highly significant mean performance among parents and crosses for fiber fineness were detected in the two $F_{1}$ and $F_{2}$ generations, revealing that there are sufficient variability existed in these populations. The mean performance of par- ents suggested that Giza 11parent was more fiber fineness than the other parents which recorded lowest values of fiber fineness; 122.10, 124.07 and $110.44 \mathrm{~mm} / \mathrm{mg}$ in $F_{1}, F_{2} \mathrm{D} 1$ and $F_{2} \mathrm{D} 2$, respectively, followed by Sakha 6 which gave values of 127.61 , 125.88 and $112.54 \mathrm{~mm} / \mathrm{mg}$ for the same order, respectively. Whereas S. 402/1parent was low fiber fineness which having highest means values of $188.01,189.85$ and $175.17 \mathrm{~mm} / \mathrm{mg}$ in, respectively $\mathrm{F}_{1}, \mathrm{~F}_{2} \mathrm{D} 1$ and $\mathrm{F}_{2} \mathrm{D} 2$.

Respect to crosses performance, data illustrated that the crosses P1xP5, P1xP2 and P2xP5 were extra of fiber fineness which recorded lowest values of $141.22,139.65$ and125.70 mm/mg, 143.66, 140.95 and $127.51 \mathrm{~mm} / \mathrm{mg}$ and 143.75 , 140.82 and $125.71 \mathrm{~mm} / \mathrm{mg}$ in the first season $\left(F_{1}\right)$ and early and late sowing dates in the second season $\left(F_{2}\right)$, respectively, with note that Giza 11 and Sakha 6 were extra of fiber fineness parents which involved in this crosses. On the other side, P1xP3 cross was the more roughness and gave highest values of $198.45,195.35$ and 180.48 $\mathrm{mm} / \mathrm{mg}$ followed by P3xP4 and P3xP6 crosses which giving $188.79,190.36$ and $177.81 \mathrm{~mm} / \mathrm{mg}$ and $186.65,190.53$ and $176.32 \mathrm{~mm} / \mathrm{mg}$ in $F_{1}, F_{2} \mathrm{D} 1$ and $\mathrm{F}_{2} \mathrm{D} 2$, respectively.

Similar results of mean performance for straw yield and its related characters were obtained by Kandil et al (2010), Kandil et al (2011), Abd ElMohsen et al (2013), Ghanbari-odivi et al (2013), Bakry et al (2014), Elayan et al (2015) and Maurya et al (2017).

\section{Analysis of combining ability variances for dif- ferent traits}

The analysis of variance for combining ability was performed using Method 2 Model 1 of Griffing, 1956. Partitioning of genetic variance to general (GCA) and specific (SCA) combining abilities are given in Table (4). GCA variances are in general attributed to additive and additive $x$ additive gene effects, while SCA variances are attributed to non- additive gene effects which involve dominance and epistasis components of the genetic variation. Partitioning of the genetic variance to GCA and SCA variances for each trait were given in Table (4). General and specific combining ability mean squares were found to be highly significant for straw yield and its components in the $F_{1}, F_{2} D 1$ and $F_{2} D 2$ (except of GCA for technical stem length in $F_{1}$ and fiber length in $F_{2} D 2$ ), indicating the importance of both additive and non-additive gene effects in the expression of these traits. 
Performance and combining ability for straw yield and related characters in a diallel cross of flax (linum usitatissmum, I.) under different sowing dates

Table 3. Mean performance of the eight parents and their 28 hybrids for studied characters during 2015/2016 $\left(F_{1}\right)$ and 2016/17 $\left(F_{2}\right)$ at early $\left(F_{2} D 1\right)$ and late $\left(F_{2} D 2\right)$ sowing dates

\begin{tabular}{|c|c|c|c|c|c|c|c|c|c|c|c|c|c|}
\hline \multirow{2}{*}{\multicolumn{2}{|c|}{ Genotypes }} & \multicolumn{3}{|c|}{ Straw yield/plant (g) } & \multicolumn{3}{|c|}{ Plant height (cm) } & \multicolumn{3}{|c|}{ Technical stem length $(\mathbf{c m})$} & \multicolumn{3}{|c|}{ Fiber yield/plant (g) } \\
\hline & & \multirow{2}{*}{$\frac{F_{1}}{27.23}$} & \multirow{2}{*}{$\begin{array}{l}\mathrm{F}_{2} \mathrm{D} 1 \\
26.83\end{array}$} & \multirow{2}{*}{$\frac{F_{2} \mathrm{D} 2}{23.50}$} & \multirow{2}{*}{$\frac{\mathbf{F}_{1}}{104.13}$} & \multirow{2}{*}{$\begin{array}{c}\mathbf{F}_{\mathbf{2}} \mathrm{D} \mathbf{1} \\
104.03\end{array}$} & \multirow{2}{*}{$\frac{F_{2} \mathbf{D} 2}{98.99}$} & \multirow{2}{*}{$\begin{array}{c}\mathbf{F}_{1} \\
69.58\end{array}$} & \multirow{2}{*}{$\begin{array}{l}F_{2} \mathrm{D} 1 \\
63.81\end{array}$} & \multirow{2}{*}{$\frac{F_{2} \mathbf{D} 2}{64.55}$} & \multirow{2}{*}{$\frac{F_{1}}{3.30}$} & \multirow{2}{*}{$\frac{\mathrm{F}_{2} \mathrm{D} 1}{3.24}$} & \multirow{2}{*}{$\frac{F_{2} \mathrm{D} 2}{2.58}$} \\
\hline S. $2465 / 1 / 3$ & P1 & & & & & & & & & & & & \\
\hline Sakha 6 & P2 & 24.53 & 23.25 & 23.33 & 91.56 & 91.91 & 85.81 & 54.41 & 54.27 & 57.98 & 2.96 & 2.89 & 2.26 \\
\hline S. $402 / 1$ & P3 & 29.13 & 28.50 & 23.63 & 110.70 & 113.30 & 107.06 & Th & 2.53 & 69.66 & 3.34 & & 2.43 \\
\hline Sakha 5 & P4 & 24.07 & 26.25 & 19.17 & 14.50 & 113.80 & & 78.83 & 76.87 & 74.04 & 2.90 & 2.72 & 2.04 \\
\hline Giza 11 & P5 & 26.57 & 28.25 & 22.48 & 90.57 & 90.29 & 84.67 & 56.53 & 5.47 & 53.72 & 3.32 & 3.26 & 2.43 \\
\hline Sakha 2 & P6 & 25.67 & 22.67 & 20.74 & 106.47 & 106.97 & 101.43 & 69.84 & 1.37 & 63.50 & 2.28 & 2.26 & 1.64 \\
\hline Giza 12 & P7 & 29.07 & 26.00 & 20.87 & 92.55 & 101.63 & 96.81 & 66.67 & 61.33 & 59.61 & 2.61 & 2.68 & 1.93 \\
\hline Jowhar & P8 & 24.00 & 21.67 & 21.33 & 95.60 & 96.68 & 90.84 & 64.64 & 64.10 & 63.62 & 2.61 & 2.59 & 2.23 \\
\hline \multicolumn{2}{|c|}{ Parents mean } & 26.28 & 25.43 & 21.88 & 100.76 & 102.33 & 96.63 & 67.00 & 63.72 & 63.34 & 2.92 & 2.85 & 2.19 \\
\hline $\mathrm{P} 1 \mathrm{xP2}$ & & 32.37 & 28.17 & 23.67 & 104.31 & 107.64 & 102.59 & 71.41 & 66.60 & 66.25 & 3.01 & 2.98 & 2.29 \\
\hline P1xP3 & & 25.47 & 25.83 & 22.83 & 113.30 & 110.70 & 106.39 & 78.37 & 75.47 & 71.86 & 2.97 & 2.95 & 2.39 \\
\hline $\mathrm{P} 1 \mathrm{xP} 4$ & & 29.47 & 25.00 & 22.86 & 102.67 & 103.91 & 100.59 & 72.52 & 2.57 & 69.40 & 3.15 & 3.17 & 2.71 \\
\hline P1xP5 & & 23.30 & 23.33 & 22.00 & 108.20 & 107.85 & 100.87 & 73.40 & 8.83 & 67.37 & 2.33 & 2.33 & 1.94 \\
\hline P1xP6 & & 32.33 & 29.17 & 24.17 & 104.50 & 98.63 & 91.07 & 72.10 & 70.70 & 66.58 & 3.43 & 38 & 2.84 \\
\hline $\mathrm{P} 1 \mathrm{xP7}$ & & 28.63 & 28.00 & 24.50 & 111.86 & 101.03 & 97.33 & 80.23 & 72.97 & 69.82 & 2.89 & 2.85 & 2.34 \\
\hline P1xP8 & & 26.97 & 22.67 & 21.50 & 87.70 & 88.80 & 85.63 & 60.43 & 59.57 & 55.47 & 2.87 & 2.83 & 2.36 \\
\hline $\mathrm{P} 2 \mathrm{xP} 3$ & & 25.97 & 23.17 & 21.33 & 94.95 & 91.56 & 88.68 & 54.72 & 59.53 & 51.68 & 3.18 & 3.20 & 2.68 \\
\hline $\mathrm{P} 2 \mathrm{xP} 4$ & & 21.13 & 23.17 & 21.33 & 104.37 & 104.62 & 100.48 & 72.93 & 2.27 & 69.30 & 3.27 & 3.24 & 2.76 \\
\hline P2xP5 & & 36.30 & 34.83 & 31.00 & 110.09 & 95.30 & 92.08 & 77.16 & 8.37 & 70.07 & 2.99 & 2.99 & 2.54 \\
\hline $\mathrm{P} 2 \mathrm{xP6}$ & & 23.43 & 21.33 & 20.83 & & & & 68.39 & 0.40 & & 3.17 & & 2.71 \\
\hline $\mathrm{P} 2 \mathrm{xP} 7$ & & 35.10 & 35.67 & 30.67 & 109.47 & 103.50 & 100.76 & 77.80 & 78.00 & 71.29 & 2.74 & 2.80 & 2.63 \\
\hline P2xP8 & & 23.00 & 23.33 & 21.67 & 111.63 & 101.03 & 98.23 & 74.03 & 75.03 & 68.28 & 3.38 & 3.33 & 2.94 \\
\hline P3xP4 & & 31.60 & 28.83 & 25.50 & 105.88 & 106.53 & 102.28 & 71.30 & 70.10 & 65.33 & 3.10 & 3.08 & 2.72 \\
\hline P3xP5 & & 24.87 & 23.67 & 21.00 & 98.52 & 102.00 & 98.28 & 63.08 & 6.00 & 57.45 & 2.56 & 2.55 & 2.04 \\
\hline P3xP6 & & 24.70 & 23.33 & 23.33 & 110.05 & 107.63 & 102.43 & 76.90 & 9.90 & 72.34 & 3.18 & 3.18 & 2.76 \\
\hline $\mathrm{P} 3 \times \mathrm{P} 7$ & & 32.37 & 31.00 & & & & 98.20 & 66.93 & & & 2.51 & & 2.08 \\
\hline P3xP8 & & 23.17 & 23.83 & 22.17 & 106.07 & 105.07 & 100.55 & 71.60 & 1.50 & 65.81 & 3.14 & & 2.68 \\
\hline $\mathrm{P} 4 \mathrm{xP5}$ & & 30.47 & 30.00 & 22.67 & 102.67 & 100.07 & 9580 & 64.13 & 67.37 & 61.18 & 2.76 & 2.59 & 2.08 \\
\hline $\mathrm{P} 4 \mathrm{xP} 6$ & & 27.70 & 26.67 & 20.50 & 106.87 & 105.70 & 101.01 & 72.03 & 68.03 & 69.19 & 3.31 & 3.73 & 3.35 \\
\hline $\mathrm{P} 4 \mathrm{xP7}$ & & 30.13 & 30.33 & 25.50 & 102.34 & 101.40 & 96.50 & 63.80 & 64.80 & 60.67 & 2.51 & 2.60 & 2.14 \\
\hline P4xP8 & & 24.47 & 23.17 & 20.33 & 111.14 & 111.00 & 105.72 & 77.75 & 72.00 & 71.05 & 2.94 & & 2.66 \\
\hline $\mathrm{P} 5 \mathrm{xP} 6$ & & 29.30 & 29.17 & 25.83 & 113.63 & 107.23 & 103.69 & 77.23 & & 71.83 & 3.04 & & 2.54 \\
\hline $\mathrm{P} 5 \times \mathrm{P} 7$ & & 36.60 & 33.50 & 27.17 & 110.17 & 115.35 & 105.37 & 73.67 & 73.23 & 66.95 & 3.46 & & 2.80 \\
\hline P5xP8 & & 29.57 & 28.50 & 23.33 & 109.23 & 104.97 & 99.18 & 75.30 & 74.30 & 68.33 & 2.77 & 2.83 & 2.40 \\
\hline P6xP7 & & 26.47 & 26.17 & 21.83 & 91.51 & 91.40 & 87.53 & 62.90 & 60.33 & 56.79 & 2.71 & 2.70 & 2.35 \\
\hline P6xP8 & & 32.63 & 32.33 & 28.50 & 107.67 & 105.50 & 101.53 & 73.07 & 73.73 & 67.34 & 3.08 & 3.07 & 2.53 \\
\hline P7xP8 & & 27.00 & 27.67 & 21.33 & 94.02 & 94.37 & 90.68 & 65.20 & 65.00 & 59.19 & 2.75 & 2.79 & 2.32 \\
\hline \multicolumn{2}{|c|}{ Crosses mean } & 28.38 & 27.21 & 23.73 & 104.91 & 102.97 & 98.26 & & 69.55 & 65.52 & 2.97 & 2.99 & 2.52 \\
\hline \multicolumn{2}{|c|}{ General mean } & 27.91 & 26.81 & 23.32 & 103.98 & 102.83 & 97.90 & 70.12 & 68.25 & 65.04 & 2.96 & 2.96 & 2.45 \\
\hline \multicolumn{2}{|c|}{ L.S.D. at 0.05} & 2.60 & 4.56 & 1.79 & 10.76 & 10.65 & 8.44 & 10.33 & 8.22 & 7.13 & 0.49 & 0.20 & 0.24 \\
\hline L.S.D.at 0 & & 3.44 & 6.06 & 2.38 & 14.28 & 14.14 & 11.21 & 13.71 & 10.92 & 9.47 & 0.64 & 0.27 & 0.32 \\
\hline
\end{tabular}


Table 3. Cont.

\begin{tabular}{|c|c|c|c|c|c|c|c|c|c|c|}
\hline \multirow{2}{*}{ Genotypes } & & \multicolumn{3}{|c|}{ Fiber percentage (\%) } & \multicolumn{3}{|c|}{ Fiber length (cm) } & \multicolumn{3}{|c|}{ Fiber fineness (mm/mg) } \\
\hline & & $F_{1}$ & $\mathrm{~F}_{2} \mathrm{D} 1$ & $F_{2} \mathrm{D} 2$ & $\mathbf{F}_{1}$ & $\mathrm{~F}_{2} \mathrm{D} 1$ & $\mathrm{~F}_{2} \mathrm{D} 2$ & $F_{1}$ & $\mathrm{~F}_{2} \mathrm{D} 1$ & $\mathrm{~F}_{2} \mathrm{D} 2$ \\
\hline S. $2465 / 1 / 3$ & $\mathrm{P} 1$ & 12.15 & 12.09 & 10.98 & 67.13 & 54.38 & 56.10 & 134.70 & 135.35 & 119.51 \\
\hline Sakha 6 & $\mathrm{P} 2$ & 12.10 & 12.44 & 9.70 & 57.80 & 51.50 & 49.51 & 127.61 & 125.88 & 112.54 \\
\hline S. $402 / 1$ & P3 & 11.52 & 11.15 & 10.27 & 72.37 & 55.78 & 62.34 & 188.01 & 189.85 & \\
\hline Sakha 5 & $\mathrm{P} 4$ & 12.08 & 10.50 & 10.65 & 76.30 & 68.50 & 67.18 & 151.75 & & \\
\hline Giza 11 & P5 & 12.50 & 11.54 & 10.80 & 53.70 & 52.85 & 48.78 & 122.10 & 124.07 & 110.44 \\
\hline Sakha 2 & P6 & 8.90 & 10.13 & 7.91 & 67.67 & 58.45 & 54.81 & 165.11 & 167.22 & 153.94 \\
\hline Giza 12 & P7 & 8.92 & 10.31 & 9.24 & 56.80 & 62.80 & 53.86 & 163.06 & 164.69 & 150.29 \\
\hline Jowhar & P8 & 10.86 & 11.96 & 10.45 & 61.83 & 60.90 & 55.99 & 153.39 & 154.37 & 139.96 \\
\hline \multicolumn{2}{|c|}{ Parents mean } & 11.13 & 11.27 & 10.00 & 64.20 & 58.15 & 56.07 & 150.72 & 152.07 & 137.85 \\
\hline P1xP2 & & 9.31 & 11.06 & 9.69 & 69.17 & 58.88 & 60.63 & 143.66 & 140.95 & 127.50 \\
\hline P1xP3 & & 11.75 & 11.47 & 10.50 & 76.13 & 64.55 & 68.18 & 198.45 & 195.35 & \\
\hline $\mathrm{P} 1 \times \mathrm{P} 4$ & & 10.74 & 12.78 & 11.86 & 71.10 & 64.65 & 62.37 & 159.25 & & \\
\hline P1xP5 & & 9.98 & 10.16 & 8.82 & & 60.75 & & 141.22 & & \\
\hline P1xP6 & & 10.64 & 12.16 & 11.79 & 69.97 & 63.38 & 62.26 & 173.43 & & \\
\hline P1xP7 & & 10.11 & 10.20 & 9.53 & 77.53 & 65.05 & 69.48 & 172.47 & 62 & 155.83 \\
\hline P1xP8 & & 10.62 & 12.59 & 10.99 & 58.03 & 51.32 & 50.17 & 159.68 & 169.91 & 156.89 \\
\hline P2xP3 & & 12.28 & 13.83 & 12.61 & 52.10 & 52.68 & 44.69 & 164.26 & 160.67 & 147 \\
\hline P2xP4 & & 15.41 & 14.08 & 12.96 & 70.87 & 67.15 & & 165 & & \\
\hline & & 8.29 & & & 75.00 & & & & & \\
\hline P2xP6 & & 13.60 & 15.1 & 13.02 & & & & & & \\
\hline P2xP7 & & 7.91 & 7.89 & 8.60 & 74.90 & 69.65 & 66.15 & 177.42 & & \\
\hline P2xP8 & & 14.76 & 14.33 & 13.60 & 71.20 & 67.62 & 63.10 & 161.98 & & \\
\hline P3xP4 & & 9.92 & 10.71 & 10.66 & 68.73 & 62.15 & 61.31 & 188.79 & 190.36 & 177 \\
\hline & & 10.35 & 10.9 & 9.74 & 59.87 & 58.88 & 51.26 & 166 & & \\
\hline & & 12.87 & 13.65 & 11.85 & & & & 186 & & \\
\hline & & 7.77 & & & & & & & & \\
\hline P3xP8 & & 13.58 & 13.41 & 12.16 & 68.90 & 63.98 & & 167.69 & & \\
\hline P4xP5 & & 9.12 & 8.68 & 9.18 & 61.50 & 60.08 & 53.47 & 168.08 & 165.43 & 152.62 \\
\hline P4xP6 & & 11.95 & 13.94 & 16.42 & 69.20 & 65.90 & 60.82 & 174.56 & 171.67 & 156.23 \\
\hline P4xP7 & & 8.32 & 8.59 & 8.41 & 61.30 & 58.05 & 53.09 & 171.48 & 169.97 & \\
\hline P4xP8 & & 12.04 & 13.46 & 13.11 & 74.87 & 64.28 & 66.79 & 166.46 & 163.84 & \\
\hline & & 10.43 & 10.59 & 9.85 & 74.77 & 63.42 & 67.58 & 171.53 & & \\
\hline P5xP7 & & 9.44 & 9.81 & 10.31 & 70.30 & 71.68 & 62.62 & 172.69 & & \\
\hline P5xP8 & & 9.36 & 10.01 & 10.37 & 72.00 & 70.42 & & 160.25 & 158.70 & 144.6 \\
\hline P6xP7 & & 10.29 & 10.45 & 10.80 & 59.73 & 56.48 & 53.39 & 172.28 & 176.23 & 164.16 \\
\hline P6xP8 & & 9.43 & & & 70.43 & 66.02 & 62.53 & 169.55 & 172.42 & 157.70 \\
\hline P7xP8 & & 10.18 & 10.11 & 10.86 & 61.90 & 58.60 & 54.30 & 167.18 & 163.88 & 149.37 \\
\hline \multicolumn{2}{|c|}{ Crosses mean } & 10.73 & 11.30 & 10.80 & 68.40 & 62.66 & 60.37 & 168.65 & 167.36 & 153.47 \\
\hline \multicolumn{2}{|c|}{ General mean } & 10.82 & 11.29 & 10.63 & 67.47 & 61.66 & 59.42 & 164.66 & 163.96 & 150.00 \\
\hline \multicolumn{2}{|c|}{ L.S.D. at 0.05} & 2.00 & 1.98 & 1.43 & 9.59 & 7.00 & 9.20 & 3.18 & 1.71 & 2.71 \\
\hline \multicolumn{2}{|c|}{ L.S.D. at 0.01} & 2.66 & 2.63 & 1.90 & 12.73 & 9.30 & 12.22 & 4.22 & 2.26 & 3.60 \\
\hline
\end{tabular}




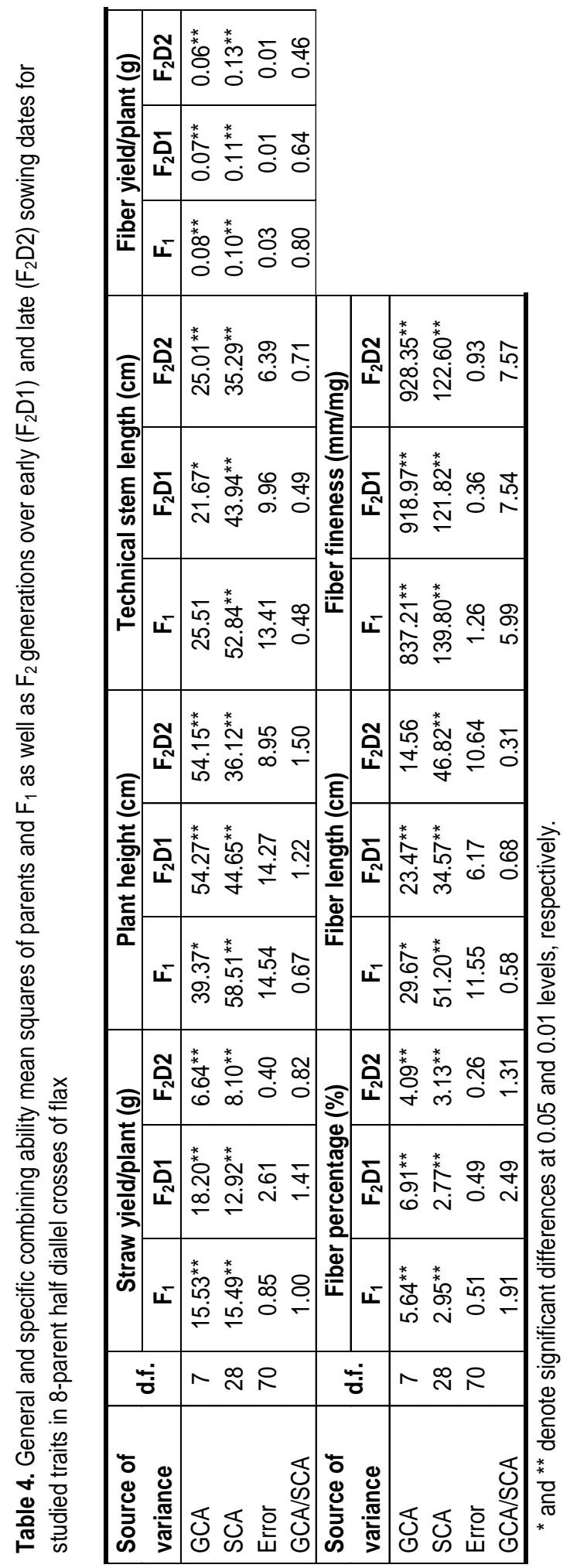


The ratios of GCA/SCA variances were greater than unity under all studied environments for straw yield/plant (except at $F_{2} D 2$ ), plant height (except at $F_{1}$ ), fiber percentage, fiber fineness, indicating that the inheritance of these traits were mainly controlled by additive gene effects. However, ratios were less than unity under all studied cases for technical stem length, fiber yield/plant and fiber length, illustrated that these traits were mainly controlled by the non-additive gene effects. In this connection, El-Farouk et al (1998) found that the mean squares of variances due to general and specific combining ability were significant for straw yield, plant height and technical stem length; also he showed that the higher magnitude of variance due to general combining ability for straw yield, plant height, technical stem length was predominantly influenced by additive gene effects.

\section{Estimates of general and specific combining} ability effects

\section{Straw yield/plant}

Estimates of general combining ability (GCA) effects for straw yield/plant are recorded in Table (5). Results indicated that the varieties Giza 12 followed by Giza 11 showed high significant positive general combining ability values under all studied cases. Therefore, it could be concluded that these two parent appeared to be the best combiner for straw yield/plant. Contrary, the parents Jowhar and Sakha 5 manifested highly significant negative (GCA) effects. Therefore, the parents behaved as the poor combiners for straw yield/plant.

Estimates of specific combining ability (SCA) effects for straw yield/plant are recorded in Table (6). Data showed that the 12 and 10 out of 28 crosses had highly significant positive (SCA) effects under studied environments $\left(F_{1}, F_{2} D 1\right.$ and $\left.F_{2} D 2\right)$, respectively, ranging from 0.93 for ( $\left.\mathrm{P} 4 \times \mathrm{P} 6\right)$, 1.32 for (P5xP6) and 0.96 for (P1xP4) to 7.64 for (P2xP5), 7.95 for (P6xP8) and 6.36 for (P6xP8) at $F_{1}, F_{2} D 1$ and $F_{2} D 2$, respectively. Therefore these crosses were considered as the best $F_{1}$ and $F_{2}$ cross combination for this trait. On the other side, highly significant negative (SCA) effects for the same trait were observed in 13,10 and 11 out of 28 hybrids at $F_{1}, F_{2} D 1$ and $F_{2} D 2$, respectively. Thus these hybrids seemed to be poor crosses for this trait. Eight crosses showed highly significant negative (SCA) effects under all studied cases.

Seven crosses observed highly significant positive (SCA) effects under all studied cases, while the crosses P2xP5, P2xP7, P3xP7 and P5xP7, being the highest specific combinations since they involved high $\mathrm{x}$ low and high $\mathrm{x}$ high general combiner parents for improving straw yield/plant. These parents and crosses can be used as useful genetic materials for improving straw yield/plant in flax under various environmental studied.

\section{Plant height}

Estimates of general combining ability effects for each parent are presented in Table (5). The data indicated that the parent Sakha 5 is good combiner for tallness due to their highly significant positive GCA values under all studied environments, while the parent line S. 402/1 was good combiner for tallness due to significant positive GCA values under $F_{2} D 1$ and $F_{2} D 2$. On the other hand, the parents Giza 12 at $F_{1}$, Sakha 6 in $F_{2} D 1$ and $F_{2} \mathrm{D} 2$ and Jowhar at $\mathrm{F}_{2} \mathrm{D} 2$ proved to be poor combiners for plant height as they attained highly significant negative GCA values. The rest parents showed insignificant GCA effects under all studied environments for this trait.

Specific combining ability effects calculated for each cross regarding plant height are presented in Table (6). The data observed that 12,11 and 10 out of 28 crosses had highly significant positive SCA effects under all studied environments, ranging from 3.05 (P3xP6), 3.33 (P2xP8) and 4.49 (P1xP5) to 10.80 (P2xP8), 15.02 (P5xP7) and 10.23 (P5xP7) in $F_{1}, F_{2} D 1$ and $F_{2} D 2$, respectively. Nine crosses showed highly significant positive SCA effects under all studied environments. Therefore, all these crosses combination are considered as good $F_{1}$ and $F_{2}$ hybrids for this trait under their respective environments. These crosses can be used as useful genetic materials for improving plant height in flax under various environmental studied.

On the other side, 7, 8 and 7 out of 28 crosses showed highly significant negative SCA effects in $F_{1}, F_{2} D 1$ and $F_{2} D 2$, respectively. Five crosses showed highly significant negative SCA effects under all studied cases. Thus, these crosses are considered as poor cross combination for plant height.

\section{Technical stem length}

Concerning to technical stem length, results indicated that the parent Sakha 5 showed high significant positive GCA effects under $F_{2} D 1$ and $F_{2} D 2$. Therefore, it could be concluded that this genotype appeared to be the best combiner for technical stem length. On the other hand, the two varieties Sakha 6 and Giza 12 in the manifested significant 
negative GCA effects under $F_{1}$ and $F_{2} D 2$, respectively, revealing that these two parents behaved as poor combiners for this trait.

Specific combining ability effects calculated for each cross regarding technical stem length are presented in Table (6). Four crosses exhibited significant or highly significant positive SCA effects were found under all studied environments Viz., $\mathrm{P} 1 \mathrm{xP7}, \mathrm{P} 2 \mathrm{xP} 5, \mathrm{P} 2 \mathrm{xP} 7$ and P5xP8, revealing that these crosses seemed to be good crosses combination for technical stem length. These crosses can be used as useful genetic materials for improving technical stem length in flax under various environmental studied. In contrast, four hybrids observed significant or highly significant negative SCA effects were found under all studied environments, this results illustrated that these hybrids are considered as poor cross combinations for technical stem length.

\section{Fiber yield/plant}

Estimates of general combining ability effects for each parent are presented in Table (5). The results revealed that Sakha 6 appeared to be the best combiner for fiber yield/plant under each environment due to its significant positive GCA effects. On the other hand, Giza 12 was poor combiner for fiber yield/plant under each environment due to its significant negative GCA effects. While, Giza 11 was poor combiner for fiber yield/plant under $F_{2} D 1$ and $F_{2} D 2$ because its significant negative GCA effects.

The specific combining ability effects calculated for each cross regarding fiber yield/plant are presented in Table (6). Results show that seven crosses gave the highest significant positive SCA effects under all studied environments. Therefore, these crosses combination are considered as good $F_{1}$ and $F_{2}$ hybrids for increasing fiber yield/plant under their respective environments. In contrast, five crosses showed highly significant negative SCA effects under all environments. Therefore, these crosses are considered as poor cross combinations for fiber yield/plant.

\section{Fiber percentage}

Estimates of general combining ability (GCA) effects for fiber percentage are recorded in Table (5). Results indicated that Jowhar parent showed high significant positive general combining ability values under all studied cases. Therefore, it could be concluded that this parent appeared to be the best combiner for fiber percentage. While Sakha 6 , S. $402 / 1$ and Sakha 5 observed significant positive general combining ability values in $F_{1}$, in addition to Sakha 6 and Sakha 5 gave high significant positive general combining ability values under $F_{2} D 1$ and $F_{2} D 2$, respectively. Contrary, the parents Giza 12 and Giza 11 manifested highly significant negative (GCA) effects. Therefore, these parents behaved as the poor combiners for this trait.

With respect to specific combining ability estimates, Table (6) indicated that highly significant positive SCA effects were found in six crosses Viz, P2xP4, P2xP6, P2xP8, P3xP6, P3xP8 and P4xP6. Therefore, these crosses combination are considered as the good $F_{1}$ and $F_{2}$ hybrids for this trait under their respective environments. On the other side, eight crosses Viz P1xP2, P2xP5, P2xP7, P3xP4, P3xP7, P4xP5, P4xP7 and P6xP8 showed highly significant negative SCA effects under all studied environments. Therefore, these crosses are considered as the poor combination for this trait. It is worthy to mention that the crosses which exhibited high significant positive SCA effects, contained two crosses; (Sakha $6 \times$ Jowhar) and (S. $402 / 1 \times$ Jowhar), included high $x$ low general combiner parents, these parents and crosses can be used to improving fiber percentage under their respective environments.

\section{Fiber length}

Concerning fiber length, estimates of general combining ability effects for each parent are presented in Table (5). The data indicated that the parent Sakha 5 was good combiner for fiber length under all studied environments due to its significant positive GCA values. Whereas, the parent line S. $2465 / 1 / 3$ was significant positive only at $F_{1}$. On the other hand, Giza 12, S. 2465/1/3 and S. $402 / 1$ showed significant negative GCA values at $F_{1}$ and $F_{2} D 1$, respectively. Therefore, these crosses are considered as the poor combination for this trait under these cases.

Specific combining ability effects calculated for each cross regarding fiber length are presented in Table (6). Seven crosses exhibited highly significant positive SCA effects were found under all studied environments Viz., P1xP7, P2xP5, P2xP7, P2xP8, P3xP6, P5xP7 and P5xP8, revealing that these crosses seemed to be good crosses combination for increasing fiber length. In contrast, five hybrids observed highly significant negative SCA effects were found under all studied environments, this results illustrated that these hybrids are considered as poor cross combinations for fiber length. 


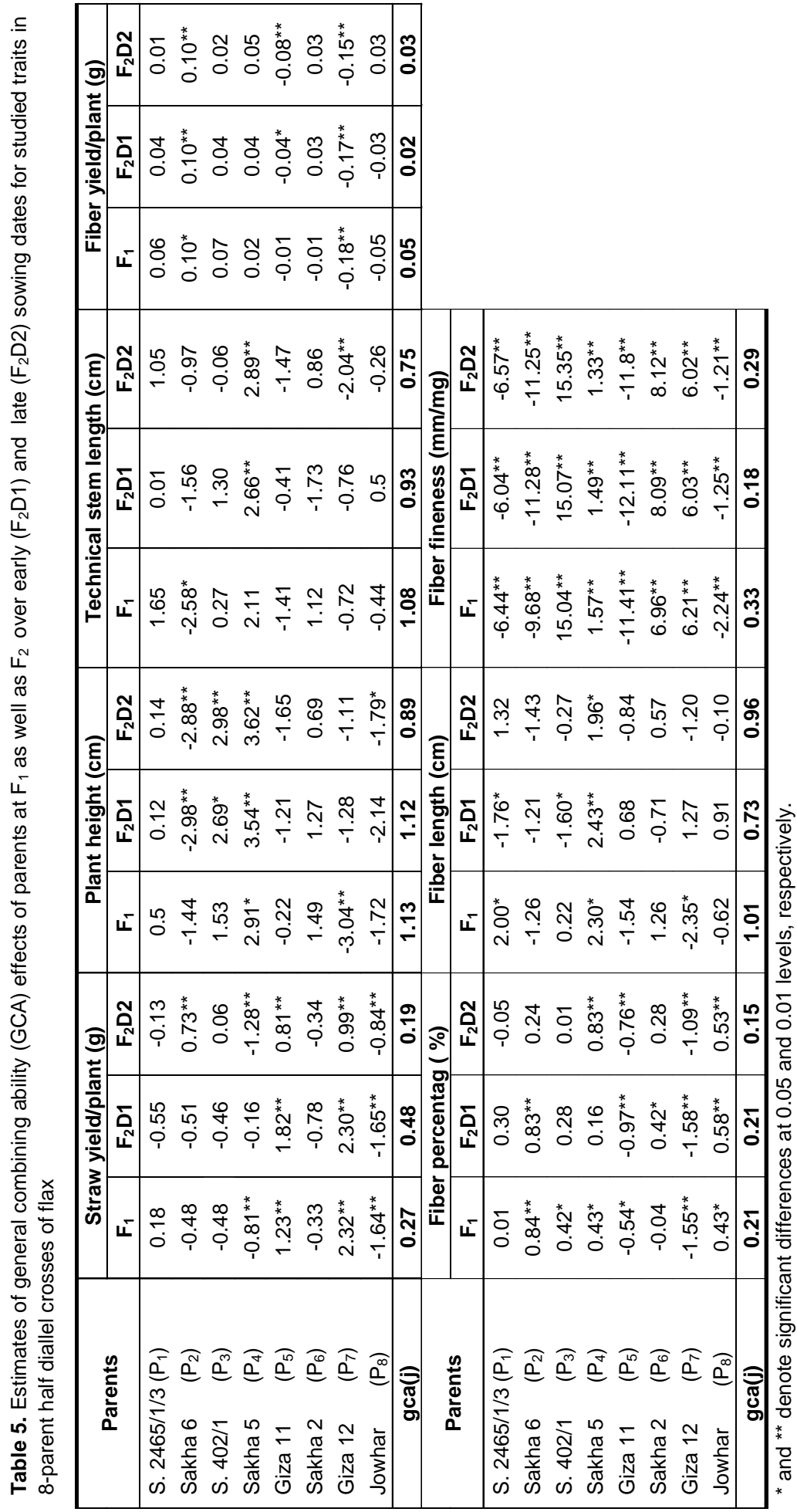


Performance and combining ability for straw yield and related characters in a diallel cross of flax (linum usitatissmum, I.) under different sowing dates

Table 6. Estimates of specific combining ability (SCA) effects of parents and $F_{1}$ as well as $F_{2}$ generation over early $\left(\mathrm{F}_{2} \mathrm{D} 1\right)$ and late $\left(\mathrm{F}_{2} \mathrm{D} 2\right)$ sowing dates for studied traits in 8-parent half diallel crosses of flax

\begin{tabular}{|c|c|c|c|c|c|c|c|c|c|c|c|c|}
\hline \multirow{2}{*}{ Crosses } & \multicolumn{3}{|c|}{ Straw yield/plant $(g)$} & \multicolumn{3}{|c|}{ Plant height $(\mathrm{cm})$} & \multicolumn{3}{|c|}{ Technical stem length $(\mathrm{cm})$} & \multicolumn{3}{|c|}{ Fiber yield/plant (g) } \\
\hline & $F_{1}$ & $F_{2} \mathrm{D} 1$ & $\mathrm{~F}_{2} \mathrm{D} 2$ & $F_{1}$ & $F_{2} \mathrm{D} 1$ & $\mathrm{~F}_{2} \mathrm{D} 2$ & $\mathbf{F}_{1}$ & $\mathrm{~F}_{2} \mathrm{D} 1$ & $\mathrm{~F}_{2} \mathrm{D} 2$ & $\mathbf{F}_{1}$ & $\mathrm{~F}_{2} \mathrm{D}_{1}$ & $F_{2} D_{2}$ \\
\hline $\mathrm{P}_{1} \times \mathrm{P}_{2}$ & $4.76^{* *}$ & $2.42^{* *}$ & -0.25 & 1.26 & $7.68^{* *}$ & $7.43^{* *}$ & 2.64 & -1.10 & 1.13 & -0.11 & $-0.11^{* *}$ & $-0.26^{* *}$ \\
\hline $\mathrm{P}_{1} \times \mathrm{P}_{3}$ & $-2.15^{\star *}$ & 0.03 & -0.41 & $7.29^{* *}$ & $5.06^{\star *}$ & $5.37^{* *}$ & 3.84 & 5.91 & $5.82^{* *}$ & -0.12 & $-0.09^{* *}$ & $-0.07^{*}$ \\
\hline $\mathrm{P}_{1} \times \mathrm{P}_{4}$ & $2.18^{* *}$ & -1.10 & $0.96^{* *}$ & $-4.71^{* *}$ & -2.57 & -1.06 & -8.01 & $1.65^{\star *}$ & 0.42 & 0.11 & $0.14^{\star *}$ & $0.22^{* *}$ \\
\hline$P_{1} \times P_{5}$ & $-6.03^{* *}$ & $-4.75^{* *}$ & $-1.99^{* *}$ & $3.94^{\star}$ & $6.12^{* *}$ & $4.49^{* *}$ & 5.5 & 0.99 & $2.75^{\star *}$ & $-0.68^{* *}$ & $-0.62^{* *}$ & $-0.43^{* *}$ \\
\hline $\mathrm{P}_{1} \times \mathrm{P}_{6}$ & $4.57^{\star *}$ & $3.68^{* *}$ & $1.32^{* *}$ & -1.47 & $-5.59^{* *}$ & $-7.66^{* *}$ & 3.23 & $4.17^{\star \star}$ & -0.36 & $0.43^{\star *}$ & $0.36^{* *}$ & $0.36^{* *}$ \\
\hline $\mathrm{P}_{1} \times \mathrm{P}_{7}$ & $-1.78^{\star *}$ & -0.57 & 0.33 & $10.43^{* *}$ & -0.63 & 0.41 & $15.31^{*}$ & $5.47^{\star \star}$ & $5.77^{\star *}$ & 0.05 & 0.03 & 0.04 \\
\hline $\mathrm{P}_{1} \times \mathrm{P}_{8}$ & 0.51 & $-1.95^{\star *}$ & $-0.85^{* *}$ & $-15.06^{* *}$ & $-12.01^{\star *}$ & $-10.62^{* *}$ & -13.14 & $-9.20^{\star *}$ & $-10.36^{\star \star}$ & -0.10 & $-0.13^{\star *}$ & $-0.12^{\star *}$ \\
\hline $\mathrm{P}_{2} \times \mathrm{P}_{3}$ & $-0.98^{* *}$ & $-2.67^{* *}$ & $-2.77^{\star *}$ & $-9.12^{* *}$ & $-10.98^{* *}$ & $-9.33^{* *}$ & $-27.49^{\star *}$ & $-8.46^{* *}$ & $-12.34^{\star *}$ & 0.05 & $0.10^{* *}$ & $0.11^{* *}$ \\
\hline $\mathrm{P}_{2} \mathrm{XP}_{4}$ & $-5.49^{\star *}$ & $-2.97^{* *}$ & $-1.43^{\star *}$ & -1.09 & 1.24 & 1.84 & -7.48 & $2.91^{*}$ & $2.35^{\star}$ & $0.18^{* *}$ & $0.15^{\star \star}$ & $0.16^{* *}$ \\
\hline $\mathrm{P}_{2} \mathrm{XP}_{5}$ & $7.64^{\star *}$ & $6.72^{* *}$ & $6.14^{* *}$ & $7.76^{* *}$ & $-3.33^{*}$ & -1.29 & $36.48^{* *}$ & $12.08^{* *}$ & $7.47^{\star *}$ & -0.06 & -0.02 & $0.07^{\star}$ \\
\hline $\mathrm{P}_{2} \times \mathrm{P}_{6}$ & $-3.67^{* *}$ & $-4.18^{* *}$ & $-2.88^{\star *}$ & -0.47 & $7.03^{* *}$ & 2.17 & -2.08 & $-4.57^{\star *}$ & $-2.10^{*}$ & 0.12 & $0.15^{\star *}$ & $0.12^{\star *}$ \\
\hline $\mathrm{P}_{2} \mathrm{XP}_{7}$ & $5.35^{\star *}$ & $7.07^{\star *}$ & $5.63^{* *}$ & $9.96^{\star *}$ & $4.94^{\star *}$ & $6.85^{\star *}$ & $16.70^{*}$ & $12.06^{\star *}$ & $9.26^{\text {** }}$ & $-0.14^{*}$ & $-0.08^{* *}$ & $0.23^{* *}$ \\
\hline $\mathrm{P}_{2} \times \mathrm{P}_{8}$ & $-2.79^{* *}$ & $-1.32^{*}$ & $-1.55^{\star *}$ & $10.80^{* *}$ & $3.33^{\star}$ & $5.00^{\star *}$ & 14.53 & $7.83^{* *}$ & $4.47^{\star \star}$ & $0.37^{* *}$ & $0.30^{\star *}$ & $0.36^{\star \star}$ \\
\hline $\mathrm{P}_{3} \mathrm{xP}_{4}$ & $4.98^{\star \star}$ & $2.65^{\star *}$ & $3.41^{* *}$ & -2.54 & -2.52 & -2.22 & -9.55 & -2.11 & $-2.54^{\star}$ & 0.05 & 0.05 & $0.20^{\star *}$ \\
\hline $\mathrm{P}_{3} \times \mathrm{P}_{5}$ & $-3.80^{* *}$ & $-4.50^{* *}$ & $-3.19^{* *}$ & $-6.77^{\star *}$ & -2.31 & -0.95 & $-16.42^{*}$ & $-3.14^{*}$ & $-6.06^{* *}$ & $-0.46^{* *}$ & $-0.40^{* *}$ & $-0.34^{* *}$ \\
\hline $\mathrm{P}_{3} \times \mathrm{P}_{6}$ & $-2.40^{* *}$ & $-2.23^{* *}$ & 0.30 & $3.05^{\star}$ & 0.84 & 0.85 & 1.90 & 2.08 & $6.50^{* *}$ & $0.17^{\star}$ & $0.15^{\star *}$ & $0.26^{\star *}$ \\
\hline $\mathrm{P}_{3} \times \mathrm{P}_{7}$ & $2.61^{* *}$ & $2.35^{\text {** }}$ & $2.64^{* *}$ & -1.5 & -1.94 & -1.57 & -11.31 & 0.91 & -1.96 & $-0.33^{* *}$ & $-0.32^{* *}$ & $-0.23^{* *}$ \\
\hline $\mathrm{P}_{3} \mathrm{xP}_{8}$ & $-2.63^{\star *}$ & -0.87 & -0.37 & 2.27 & 1.68 & 1.46 & -5.12 & 1.44 & 1.09 & $0.16^{*}$ & $0.22^{* *}$ & $0.18^{* *}$ \\
\hline $\mathrm{P}_{4} \times \mathrm{P}_{5}$ & $2.13^{\star *}$ & $1.53^{*}$ & -0.18 & $-4.00^{\star *}$ & $-5.09^{\star *}$ & $-4.07^{\star *}$ & $-18.65^{\star *}$ & $-3.13^{*}$ & $-5.27^{\star *}$ & $-0.21^{* *}$ & $-0.36^{* *}$ & $-0.33^{* *}$ \\
\hline $\mathrm{P}_{4} \times \mathrm{P}_{6}$ & $0.93^{*}$ & 0.80 & $-1.20^{* *}$ & -1.51 & -1.94 & -1.19 & -8.63 & -1.15 & 0.41 & $0.34^{* *}$ & $0.70^{\star *}$ & $0.82^{* *}$ \\
\hline $\mathrm{P}_{4} \times \mathrm{PP}_{7}$ & 0.71 & $1.38^{*}$ & $2.48^{* *}$ & -1.51 & $-3.68^{*}$ & $-3.91^{\star *}$ & $-19.07^{\star \star}$ & $-5.35^{\star *}$ & $-5.21^{\star *}$ & $-0.29^{* *}$ & $-0.22^{* *}$ & $-0.21^{* *}$ \\
\hline $\mathrm{P}_{4} \times \mathrm{P}_{8}$ & $-1.00^{\star \star}$ & $-1.83^{* *}$ & $-0.87^{\star *}$ & $5.97^{\star *}$ & $6.77^{\star *}$ & $6.00^{\star *}$ & -1.37 & 0.58 & $3.39^{* *}$ & 0.01 & $0.14^{\star *}$ & $0.14^{\star *}$ \\
\hline $\mathrm{P}_{5} \times \mathrm{P}_{6}$ & 0.48 & $1.32^{*}$ & $2.04^{* *}$ & $8.38^{* *}$ & $4.34^{\star *}$ & $6.75^{\star \star}$ & 10.58 & $5.02^{* *}$ & $7.40^{* *}$ & 0.10 & $0.14^{* *}$ & $0.14^{\star *}$ \\
\hline $\mathrm{P}_{5} \times \mathrm{P}_{7}$ & $5.13^{* *}$ & $2.57^{\star *}$ & $2.05^{\star *}$ & $9.45^{\star *}$ & $15.02^{\star *}$ & $10.23^{* *}$ & 10.5 & $6.15^{* *}$ & $5.42^{\star *}$ & $0.70^{* *}$ & $0.54^{\star *}$ & $0.59^{* *}$ \\
\hline$P_{5} \times P_{8}$ & $2.06^{\star *}$ & $1.52^{\star}$ & 0.04 & $7.19^{* *}$ & $5.49^{* *}$ & $4.72^{\star *}$ & $16.49^{*}$ & $5.95^{\star \star}$ & $5.02^{* *}$ & $-0.13^{*}$ & -0.05 & 0.00 \\
\hline $\mathrm{P}_{6} \times \mathrm{P}_{7}$ & $-3.44^{* *}$ & $-2.17^{* *}$ & $-2.14^{* *}$ & $-10.92^{* *}$ & $-11.42^{* *}$ & $-9.95^{\star *}$ & -9.95 & $-5.43^{* *}$ & $-7.06^{* *}$ & -0.05 & $-0.12^{\star *}$ & 0.20 \\
\hline $\mathrm{P}_{6} \times \mathrm{P}_{8}$ & $6.69^{* *}$ & $7.95^{\star *}$ & $6.36^{* *}$ & $3.91^{*}$ & $3.54^{*}$ & $4.73^{\star *}$ & 4.62 & $6.71^{\star *}$ & 1.71 & $0.18^{* *}$ & $0.11^{* *}$ & 0.02 \\
\hline $\mathrm{P}_{7} \times \mathrm{P}_{8}$ & $-1.60^{* *}$ & 0.20 & $-2.14^{* *}$ & $-5.20^{* *}$ & $-5.04^{\star *}$ & $-4.32^{\star *}$ & -2.20 & $-3.00^{*}$ & $-3.54^{* *}$ & 0.02 & 0.03 & -0.01 \\
\hline sca(ii) & 0.83 & 1.47 & 0.58 & 3.46 & 3.43 & 2.71 & 3.32 & 2.86 & 2.29 & 0.16 & 0.07 & 0.08 \\
\hline sca(iij) & 0.36 & 0.64 & 0.25 & 1.50 & 1.49 & 1.18 & 1.44 & 1.24 & 1.00 & 0.07 & 0.03 & 0.03 \\
\hline
\end{tabular}

* and ${ }^{* *}$ denote significant differences at 0.05 and 0.01 levels, respectively. 
Table 6. Cont.

\begin{tabular}{|c|c|c|c|c|c|c|c|c|c|}
\hline \multirow{2}{*}{ Crosses } & \multicolumn{3}{|c|}{ Fiber percentage ( \%) } & \multicolumn{3}{|c|}{ Fiber length (cm) } & \multicolumn{3}{|c|}{ Fiber fineness $(\mathrm{mm} / \mathrm{mg}$ ) } \\
\hline & $F_{1}$ & $\mathrm{~F}_{2} \mathrm{D} 1$ & $F_{2} \mathrm{D} 2$ & $F_{1}$ & $\mathrm{~F}_{2} \mathrm{D} 1$ & $F_{2} \mathrm{D} 2$ & $F_{1}$ & $\mathrm{~F}_{2} \mathrm{D} 1$ & $F_{2} \mathrm{D} 2$ \\
\hline $\mathrm{P}_{1} \times \mathrm{P}_{2}$ & $-2.36^{\star *}$ & $-1.35^{\star \star}$ & $-1.13^{* *}$ & 0.96 & 0.19 & 1.32 & $-4.88^{\star *}$ & $-5.68^{* *}$ & $-4.68^{* *}$ \\
\hline$P_{1} \times P_{3}$ & 0.50 & -0.40 & -0.09 & 6.44 & $6.25^{\star *}$ & $7.71^{* *}$ & $25.18^{\star *}$ & $22.37^{\star \star}$ & $21.69^{* *}$ \\
\hline $\mathrm{P}_{1} \times \mathrm{P}_{4}$ & -0.52 & $1.03^{* *}$ & $0.46^{*}$ & -0.66 & $2.32^{*}$ & -0.33 & -0.54 & $-2.06^{\star *}$ & $-2.32^{* *}$ \\
\hline $\mathrm{P}_{1} \times \mathrm{P}_{5}$ & -0.30 & -0.45 & $-1.00^{*}$ & $3.07^{*}$ & 0.17 & $2.80^{*}$ & $-5.59^{* *}$ & $-6.15^{\star *}$ & $-5.93^{* *}$ \\
\hline $\mathrm{P}_{1} \times \mathrm{P}_{6}$ & -0.15 & 0.15 & $0.93^{* *}$ & -0.76 & $4.19^{\star *}$ & 0.96 & $8.25^{\star \star}$ & $4.65^{\star *}$ & $4.92^{* *}$ \\
\hline $\mathrm{P}_{1} \times \mathrm{P}_{7}$ & $0.83^{* *}$ & 0.20 & 0.05 & $10.42^{* *}$ & $3.88^{* *}$ & $9.95^{* *}$ & $8.04^{* *}$ & $6.67^{\star *}$ & $6.38^{* *}$ \\
\hline $\mathrm{P}_{1} \times \mathrm{P}_{8}$ & $-0.64^{*}$ & 0.42 & -0.11 & $-10.81^{* *}$ & $-9.49^{\star *}$ & $-10.47^{* *}$ & $3.70^{\star *}$ & $13.24^{\star \star}$ & $14.67^{\star \star}$ \\
\hline $\mathrm{P}_{2} \times \mathrm{P}_{3}$ & 0.21 & $1.44^{* *}$ & $1.72^{\star *}$ & $-14.33^{\star *}$ & $-6.17^{\star *}$ & $-13.03^{* *}$ & $-5.76^{\star *}$ & $-7.07^{\star \star}$ & $-6.49^{\star *}$ \\
\hline $\mathrm{P}_{2} \mathrm{XP}_{4}$ & $3.32^{* *}$ & $1.80^{* *}$ & $1.26^{\star *}$ & 2.36 & $4.27^{\star *}$ & 2.19 & $8.98^{* *}$ & $7.47^{* *}$ & $6.60^{* *}$ \\
\hline $\mathrm{P}_{2} \mathrm{XP}_{5}$ & $-2.83^{\star \star}$ & $-2.52^{* *}$ & $-1.91^{* *}$ & $10.33^{* *}$ & $9.66^{\star *}$ & $9.19^{* *}$ & 0.18 & 0.25 & $-1.25^{\star *}$ \\
\hline $\mathrm{P}_{2} \times \mathrm{P}_{6}$ & $1.98^{* *}$ & $2.65^{\star *}$ & $1.87^{* *}$ & -1.70 & $-6.66^{\star *}$ & -0.15 & $11.39^{\star *}$ & $10.40^{\star *}$ & $9.36^{* *}$ \\
\hline $\mathrm{P}_{2} \mathrm{XP}_{7}$ & $-2.19^{* *}$ & $-2.64^{* *}$ & $-1.18^{* *}$ & $11.05^{\star *}$ & $7.93^{* *}$ & $9.36^{* *}$ & $16.23^{* *}$ & $17.11^{* *}$ & $17.04^{* *}$ \\
\hline $\mathrm{P}_{2} \times \mathrm{P}_{8}$ & $2.67^{\star \star}$ & $1.64^{\star *}$ & $2.20^{\star \star}$ & $5.61^{\star \star}$ & $6.26^{\star \star}$ & $5.21^{* *}$ & $9.24^{\star \star}$ & $8.55^{\star \star}$ & $9.35^{\star *}$ \\
\hline $\mathrm{P}_{3} \times \mathrm{P}_{4}$ & $-1.75^{\star *}$ & $-1.02^{* *}$ & $-0.81^{* *}$ & -1.25 & -0.34 & 0.20 & $7.52^{\star \star}$ & $9.84^{* *}$ & $11.14^{* *}$ \\
\hline $\mathrm{P}_{3} \mathrm{XP}_{5}$ & -0.35 & 0.34 & -0.15 & $-6.29^{* *}$ & -1.85 & $-7.04^{\star *}$ & $-2.15^{\star \star}$ & $-3.79^{\star *}$ & $-2.65^{\star *}$ \\
\hline$P_{3} \times P_{6}$ & $1.67^{\star \star}$ & $1.67^{\star \star}$ & $0.93^{* *}$ & $5.62^{\star \star}$ & $3.30^{* *}$ & $6.10^{* *}$ & -0.02 & $3.41^{* *}$ & $2.85^{\star *}$ \\
\hline $\mathrm{P}_{3} \mathrm{xP}_{7}$ & $-1.91^{* *}$ & $-1.89^{* *}$ & $-1.84^{* *}$ & -0.94 & 1.16 & -1.96 & $-1.52^{\star *}$ & $-4.19^{\star *}$ & $-4.65^{\star *}$ \\
\hline $\mathrm{P}_{3} \times \mathrm{P}_{8}$ & $1.91^{* *}$ & $1.27^{\star \star}$ & $0.99^{* *}$ & 1.83 & $3.01^{\star *}$ & 1.09 & $-9.78^{\star *}$ & $-12.09^{* *}$ & $-10.85^{\star \star}$ \\
\hline $\mathrm{P}_{4} \times \mathrm{P}_{5}$ & $-1.59^{* *}$ & $-1.80^{\star *}$ & $-1.52^{\star *}$ & $-6.73^{* *}$ & $-4.69^{\star *}$ & $-7.07^{\star *}$ & $13.26^{\star *}$ & $12.09^{\star \star *}$ & $13.09^{* *}$ \\
\hline $\mathrm{P}_{4} \times \mathrm{P}_{6}$ & $0.74^{* *}$ & $2.07^{* *}$ & $4.69^{* *}$ & -1.82 & $2.52^{*}$ & -1.12 & $1.38^{* *}$ & $-1.88^{* *}$ & $-3.22^{* *}$ \\
\hline $\mathrm{P}_{4} \times \mathrm{P}_{7}$ & $-1.38^{\star \star}$ & $-1.28^{\star *}$ & $-1.96^{\star *}$ & $-6.11^{\star *}$ & $-7.31^{\star \star}$ & $-7.08^{\star \star}$ & $-0.96^{*}$ & $-1.51^{\star *}$ & $-1.00^{*}$ \\
\hline $\mathrm{P}_{4} \times \mathrm{P}_{8}$ & 0.36 & $1.43^{* *}$ & $1.13^{\star *}$ & $5.72^{* *}$ & -0.72 & $5.51^{* *}$ & $2.47^{\star \star}$ & -0.37 & $-0.91^{*}$ \\
\hline $\mathrm{P}_{5} \times \mathrm{P}_{6}$ & 0.19 & -0.14 & -0.30 & $7.58^{\star *}$ & 1.79 & $8.44^{* *}$ & $11.32^{* *}$ & $9.51^{* *}$ & $9.87^{\star *}$ \\
\hline$P_{5} \times P_{7}$ & $0.71^{*}$ & $1.08^{\star *}$ & $1.53^{* *}$ & $6.72^{\star \star}$ & $8.08^{\star *}$ & $5.25^{\star *}$ & $13.23^{\star *}$ & $11.32^{\star *}$ & $11.16^{\star *}$ \\
\hline$P_{5} \times P_{8}$ & $-1.35^{\star \star}$ & $-0.89^{* *}$ & -0.03 & $6.69^{\star *}$ & $7.17^{\star *}$ & $6.31^{* *}$ & $9.24^{\star *}$ & $8.10^{\star *}$ & $7.61^{* *}$ \\
\hline $\mathrm{P}_{6} \times \mathrm{P}_{7}$ & $1.06^{* *}$ & 0.33 & $0.99^{* *}$ & $-6.64^{* *}$ & $-5.73^{\star \star}$ & $-5.39^{\star \star}$ & $-5.55^{\star \star}$ & $-1.85^{\star \star}$ & 0.02 \\
\hline $\mathrm{P}_{6} \times \mathrm{P}_{8}$ & $-1.79^{\star *}$ & $-2.74^{\star *}$ & $-2.54^{\star *}$ & 2.33 & $4.16^{\star \star}$ & $2.64^{*}$ & 0.17 & $1.61^{* *}$ & $0.79^{\star}$ \\
\hline $\mathrm{P}_{7} \times \mathrm{P}_{8}$ & 0.48 & -0.17 & $0.80^{* *}$ & -2.59 & $-5.23^{\star *}$ & $-3.82^{\star \star}$ & $-1.45^{\star \star}$ & $-4.86^{\star \star}$ & $-5.44^{\star *}$ \\
\hline sca(ii) & 0.64 & 0.64 & 0.46 & 3.08 & 2.25 & 2.96 & 1.02 & 0.55 & 0.87 \\
\hline sca(ij) & 0.28 & 0.28 & 0.20 & 1.34 & 0.98 & 1.29 & 0.44 & 0.24 & 0.38 \\
\hline
\end{tabular}

${ }^{*}$ and ${ }^{* *}$ denote significant differences at 0.05 and 0.01 levels, respectively. 

diallel cross of flax (linum usitatissmum, I.) under different sowing dates

\section{Fiber Fineness}

Fiber fineness results in Table (5) present general combining ability effect for each parent. Since positive values of GCA would be of interest for fiber fineness, four parents; S. 402/1 followed by Sakha 2, Giza 12 and Sakha 5 were considered to be the best among the parental set as progenitors in hybridization programs at all studied environments towards fine fiber genotypes. Four parents; S. 2465/1/3, Sakha 6, Giza 11 and Jowhar showed highly significant negative GCA effects across all studied environments. Therefore, these parents behaved as the poor combiners for fiber fineness.

Estimates of specific combining ability effects recorded in Table (6) show that 13 out of 28 hybrids had highly significant SCA effects for fiber fineness under their respective environments. Therefore it could be mentioned that these cross combinations are considered as the best hybrids for this trait. Out of these hybrids, one, nine and three hybrids included good $x$ good, good $x$ low and low $x$ low general combiner parents, respectively. These parents and crosses can be used as useful genetic materials for improving fiber fineness in flax under various environmental studied.

Results of general and specific combining ability effects for straw yield ant its related characters are in agreement with those reported by Abokaied (2002), Mohammadi et al (2010), AbdelMoneam (2014), Pali and Mehta (2014), Abd AlSadek (2015), Abd El-Haleem and Abd Al-Sadek (2015) and Nirala et al (2018).

\section{REFERENCES}

Abd El-Haleem R.A. and Maysa S. Abd AlSadek 2015. Estimation of combining ability for eight flax genotypes under sandy soil conditions. J. Plant Production Mansoura Univ., 6(3), 323-335.

Abd El-Mohsen A.A., Abdallah A.M. and Mahmoud G.O. 2013. Optimizing and describing the influence of planting dates and seeding rates on flax cultivars grown under Middle Egypt region conditions. J. Appl. Sci. Res., 9(7), 4174-4185.

Abdel-Moneam M.A. 2014. Diallel analysis for yield and its related traits in some genotypes of flax (linum usitatissimum L.). Int. J. Plant Breed. Genet., 8(3), 153-163.

Abo-Kaied H.M.H. 2002. Combining ability and gene action for yield and yield components in flax. Egypt J. PI. Breed., 6(2), 51-63.
Abo-Kaied H.M.H., Afaf E.A. Zahana and Hussein M.M.M. 2007. Diallel cross analysis for some flax genotypes under normal and saline environments. J. Agric. Sci. Mansoura Univ., 32(12), 9857- 9874.

Abo-Kaied H.M.H. and Amany M.M. El-Refaie 2008. Genetic studies on yield and its attributes in some flax hybrids under different environmental conditions. J. Agri. Sci. Mansoura Univ., 33(7), 4697- 4715.

Allard R.W. 1960. Principles of Plant Breeding. Jon Wiley and Sons Inc., New York, USA, 485 p.

Bakry B.A., Ibrahim O.M., Elewa T.A. and ElKaramany M.F. 2014. Performance assessment of some flax (Linum usitatissimum L.) varieties using cluster analysis under sandy soil conditions. Agric. Sci., 5, 677-686.

El-Farouk M., Amena H.H. El-Sweify and Afaf M. Tolba 1998. Diallel cross analysis for some agronomic characters in flax. Egypt J. Appl. Sci., 13, 110-127.

Eman A.A. El-Kady and Abo-Kaied H.M.H. 2002. Diallel cross analysis for straw, seed yields and their components in flax. J. Plant Production, Mansoura Univ., Mansoura, Egypt, 1(9), 1219 - 1231.

Foster R., Pooni H.S. and Mackay I.J. 1998. Quantitative analysis of Linum usitatissimum crosses for dual-purpose trait. J. of Agric. Sci., 131, 285- 292.

Ghanbari-odivi A., Safari A., Tahmasebi B.K., Farrokhi M. and Bahrampour B. 2013. Effect of delaying in sowing date on growth, yield, yield components and oil content of two genotypes of flaxseed (Linum usitatissimum, L). Adv. Environ. Biol., 7(6), 1014-1018.

Griffing B. 1956. Concept of general and specific combining ability in relation to diallel crossing systems. Aust. J. biol. Sci., 9, 436-493.

Hassanein M.S., Al-Kordy M.A.A. and El-Hariri D.M. 2012. Evaluation, correlation and path coefficient analysis among straw yield and its attributes of fiber flax (Linum usitatissimum L.) cultivars. J. Appl. Sci. Res., 8(3), 1539-1546.

Kandil A.A., Lellah A.A., Abou-Zaied T.A. and Heba A.H. Turky 2010. Performance of some flax varieties (Linum usitatissimum L.) under different sowing and harvesting dates: 2- seed yield and its components. J. Plant Production, Mansoura Univ., 1(7), 903-911.

Kandil A.A., Sheraif A.E., Abo-Zaied T.A. and Gamil A. 2011. Genetic divergence and heterosis in linseed (Linum ussitatissimum L.). J. 
Plant Production, Mansoura Univ., Mansoura, Egypt, 2(2), 335-349.

Maysa S. Abd Al-Sadek 2015. Diallel cross analysis for yield and its components in six flax genotypes. J. Plant Production, Mansoura Univ., Mansoura, Egypt, 6(11), 1877-1886.

Maurya A.C., Raghuveer M., Goswami G. and Kumar S. 2017. Influences of date of sowing on yield attributes and yield of linseed (Linum usitatissimum L.) varieties under dryland condition in Eastern Uttar Pradesh. Int. J. Curr. Microbiol. App. Sci., 6(7), 481-487.

Mohammadi A.A., Saeidi G. and Arzani A. 2010. Genetic analysis of some agronomic traits in flax (Linum usitatissimum L.). Australian J. of Crop Sci., 4(5), 343-352.

Nirala R.B.P., Rani N., Acharya S., Vishwakarma R., Ranjan T., Prasad B.D. and Pal A.K. 2018. Combining ability analysis for grain yield and its component traits in linseed (Linum usitatissimum L.). Current J. of App. Sci. and Techn., 31(4), 1-12.
Pali V. and Mehta N. 2014. Combining ability and heterosis for seed yield and it's attributes in linseed (Linum usitatissimum L.). The Bioscan., 9(2), 701-706.

Patil V.D. and Chopde P.R. 1981. Combining ability analysis over environments in diallel crosses of linseed (Linum usitatissimum L.). Theor. Appl. Genet., 60, 339-343.

Radwan S.R. and Momtaz A. 1966. The technological properties of flax fiber and methods of estimating them. El-Felaha., J. 46(5), 466-476 (in Arabic).

Shehata A.H. and Comstock V.E. 1971. Heterosis and combining ability estimates in $F_{2}$ flax populations as influenced by plant density. Crop Sci., 11, 534-536.

Snedecor G.W. and Cochran W.G. 1980. Statistical Methods. $7^{\text {th }}$ ed., lowa Stat. Unvi. Press, Ames, lowa, USA, pp. 225-273.

Sohair E.D. Elayan, Amany M. Abdallah, Nemat A. Naguib and Doaa I. Mahmoud 2015. Effect of sowing date on yield, fiber and seed quality of eight flax genotypes. Am-euras. J. Agric. \& Environ. Sci., 15(5), 886-895. 
مجلة اتحاد الجامعات العربية للعلوم الزراعية ، جامعة عين شمس ، القاهرة ، مصر

مجلا(27)، عدد(2)، 1440-1423، 2019

Website: http://strategy-plan.asu.edu.eg/AUJASCI/

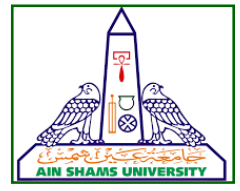

1439

السلوك والقدرة على التآلف لمحصول القش ومكوناته فى دائرة تهجينات من الكتان

تحت مواعيد زراعة مختلفة

$[117]$

أماني نبيل سيد1" - عبد المقصود محروس المراكبي 1- عفاف محمد طلبة1 - صباح محمد أبو القمصان2 2

1- قسم الحاصيل- كلية الزراعة- جامعة عين شمس- ص.ب.

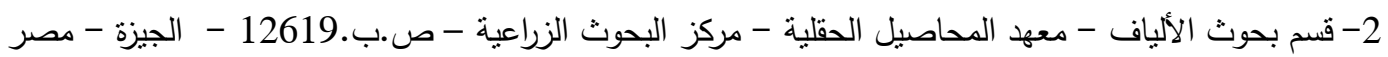

*Corresponding author: amany87323@agr.asu.eg

Received 11 April, 2019

Accepted 30 April, 2019

الوراثية الأبوية والهجن لجميع الصفات المدروسة تحت

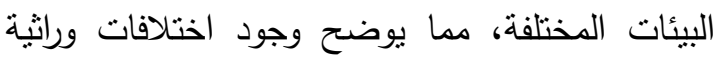

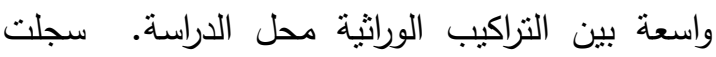

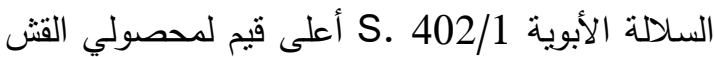
والألياف، الطول الفعال للساق ونعومة الألياف، بينما

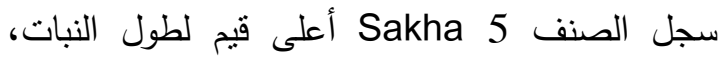

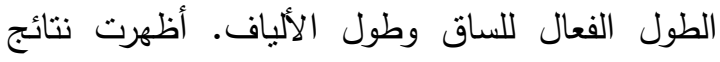
تحليل القدرة على التآلف وجود الإلى التتلافات عالية

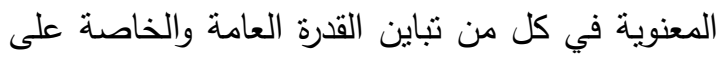

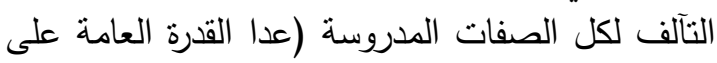

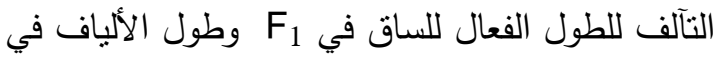

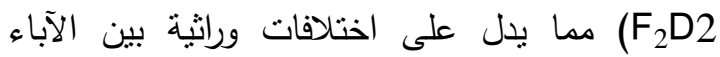
المستخدمة في هذه الدراسة، وكذلك أهمية كلا من الآناء

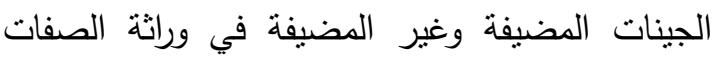

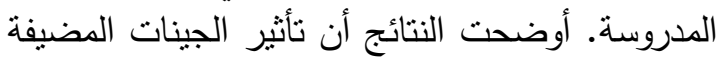
كان أكثر أهمية عن الجينات غير المضيفة في الـ

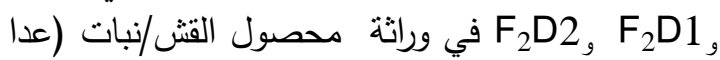

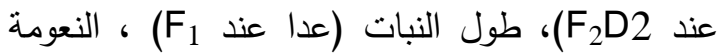

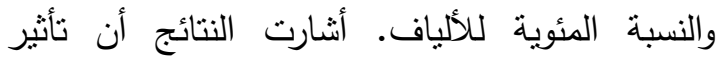

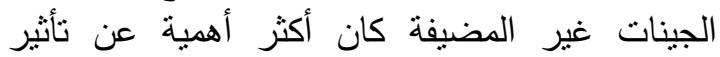

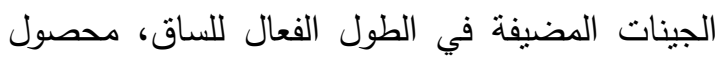
الألياف/نبات وطول الألياف. سجلت التراكيب الوراثية لإنية الأبوية Giza 11 و 12 Giza 12 لمحصول الأيان Sakha لطول النبات والألياف، Sakha 6

\section{الموج.}

أجرى هذا البحث بمحطة البحوث والتجارب الزراعبة بشلقان - محافظة القليوبية والتابعة لكلية الزراعة جامعة عين شمس وذللك لتقييم 36 نركيب

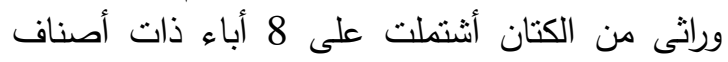
وسلالات محلية ومستوردة وذات أصول منباعدة و 28

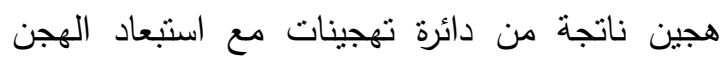

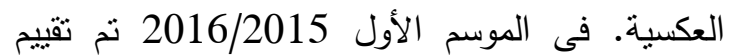

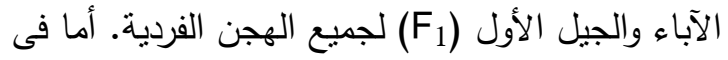

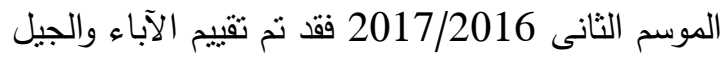
التانى الإنعزالى لجميع الهجن تحت ميعادين للزراعة أحدهما مبكر Fa تصميم قطاعات كاملة العشوائية من 3 مكررات لدراسة Griffing السلوك والقدرة على التآلف بطريقة (1956) لمحصول القش ومكوناته فى الجيلين الأول

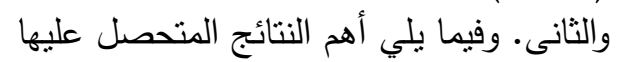
أظهر تحليل التباين وجود اختلافات عالية المعائل المنوية

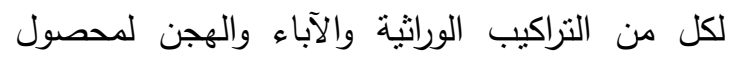

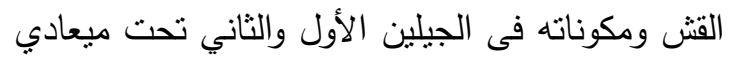

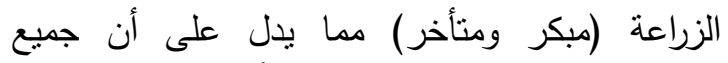

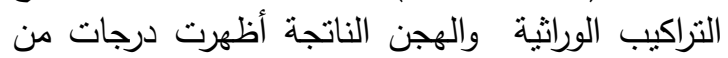

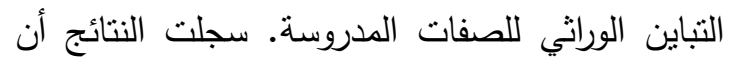

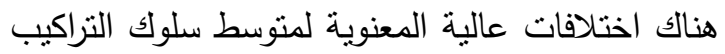


النتائج أن كل من التأثثرات المضيفة وغير المضيفة

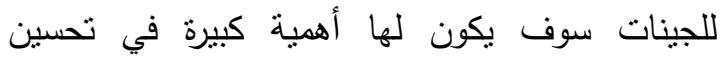
محصول القش ومكوناته عند استخدام طريقة التربية

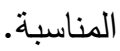

الكلمات الدالة: كتان، سلوك، القدرة على التآلف،

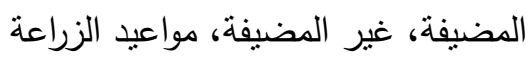

لمحصول الألياف/نبات، Jowhar للنسبة المئوية للألياف،S. 402/1 لنعومة الألياف قدرة ائتلافية جيدة

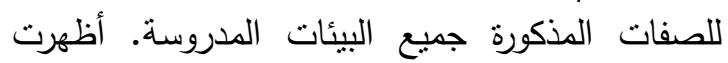

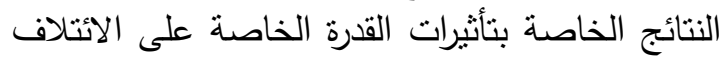

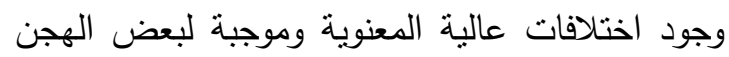

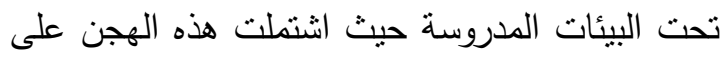

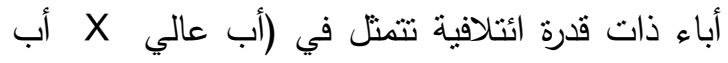
عالي) أو (أب عالي X X أب منخفض). أوضحت 